NBER WORKING PAPER SERIES

\title{
BANK CHARTERING AND POLITICAL CORRUPTION IN ANTEBELLUM NEW YORK: FREE BANKING AS REFORM
}

\author{
Howard Bodenhorn
}

Working Paper 10479

http://www.nber.org/papers/w10479

\section{NATIONAL BUREAU OF ECONOMIC RESEARCH 1050 Massachusetts Avenue Cambridge, MA 02138}

May 2004

Prepared for NBER Conference on Corruption and Reform. I thank Michael Bordo, Andrew Economopoulos, Stephen Quinn, Hugh Rockoff, Jay Shambaugh, John Wallis, Eugene White, Robert E. Wright, seminar participants at Rutgers University and the NBER, for many useful comments and suggestions. Special thanks go to Claudia Goldin who provided extensive and valuable comments on two previous drafts. The final result is much better for her asking searching questions. I thank Pam Bodenhorn for valuable research assistance. The views expressed herein are those of the author(s) and not necessarily those of the National Bureau of Economic Research.

(C2004 by Howard Bodenhorn. All rights reserved. Short sections of text, not to exceed two paragraphs, may be quoted without explicit permission provided that full credit, including (C) notice, is given to the source. 
Bank Chartering and Political Corruption in Antebellum New York: Free Banking as Reform Howard Bodenhorn

NBER Working Paper No. 10479

May 2004

JEL No. N11, G21

\section{$\underline{\text { ABSTRACT }}$}

One traditional and oft-repeated explanation of the political impetus behind free banking connects the rise of Jacksonian populism and a rejection of the privileges associated with corporate chartering. A second views free banking as an ill-informed inflationist, pro-business response to the financial panic of 1837 . This chapter argues that both explanations are lacking. Free banking was the progeny of the corruption associated with bank chartering and reflected social, political and economic backlashes against corruption dating to the late-1810s. Three strands of political thought -Antimasonic egalitarianism, Jacksonian pragmatism, and pro-business American Whiggism -converged in the $1830 \mathrm{~s}$ and led to economic reform. Equality of treatment was the political watchword of the 1830s and free banking was but one manifestation of this broader impulse.

Howard Bodenhorn

Department of Economics

Lafayette College

Easton, PA 18042

and NBER

bodenhoh@lafayette.edu 
"He saw in the system what he thought a most dangerous political engine, which might in the hands of bad men be used for bad purposes."1

\section{Introduction}

Government policies toward business can be categorized into three types: minimal, maximal, and decentralized (Frye and Shleifer 1997). A minimal policy regime, often referred to as the "invisible hand," leaves most economic decisions to private agents reserving the provision of only a few essential public goods to the state. In maximal, or "iron hand" regimes, the state is actively involved in economic activity, typically through the pursuit of industrial policies that direct resources toward sectors deemed important by politicians. Bureaucrats in maximal regimes may be corrupt, but corruption is limited and does not impede economic growth (Murphy Shleifer and Vishny 1993; Mauro 1995). In the decentralized, or "grabbing hand," regime, the state is made up of many independent bureaucracies each competing for rents that together severely undermine economic activity.

In the half century between President Washington's inauguration and President Van Buren's many of the states comprising the United States experienced abrupt transitions from fairly "iron handed" regimes to a more "invisible" ones. No where was this transition more apparent than in bank chartering policy, and no where was the transition more pronounced than in New York State, which witnessed a shift from an "iron handed" banking policy controlled by Van Buren's powerful Democratic Party machine in the early 1830s to a market-oriented policy instituted in 1838 .

In the early United States bank chartering was high-stakes politics. Because states tended to limit the number of corporate franchises, the available rents were potentially large and prospective owners spent freely in their campaigns to obtain one. Reform proposals emerged throughout the antebellum era, but significant reform did not emerge until Michigan and New York took the lead in the late 1830s. These states' response

\footnotetext{
${ }^{1}$ Luther Bradish, New York State Assemblyman, quoted in Albany Evening Journal (19 January 1837).
} 
became known as free banking. By 1860 some 18 states enacted a variant of free banking, modeled on the 1838 New York law. In this chapter I describe the events leading up to the passage of New York State's 1838 free banking statute, showing how corrupt politics and an iron-handed chartering regime gave way to free market reform and a liberal general incorporation law. A restrictive franchise with a resulting partisan distribution of political privilege in post-Revolutionary New York led to electoral reform, culminating in a revised state constitution in 1821 . Once the political issues were resolved public attention turned to the political manipulation of economic opportunities. The debate about the role of government in the economy influenced the platforms of the three dominant contemporary political parties. Ultimately, free banking represented the confluence of Antimasonic populism, Democratic pragmatism, and pro-business American Whiggism.

\section{Bank Chartering: A Legacy of Corruption in New York, 1803-1837}

\subsection{Early Chartering Practices}

Between 1790 and 1810 corporate privileges were reserved for a select few organizations, mostly nonprofit associations. Religious congregations, schools, academies and colleges, medical societies, libraries, and benevolent societies, among others, received more corporate charters than any other type of association (Evans 1948). As the number of such organizations increased, the demand for acts of incorporation consumed a growing proportion of legislative time and energy and, between 1784 and 1811, New York enacted a number of general laws for the incorporation of nonprofit organizations. The law allowing free incorporation of religious institutions is of particular note because it promised denominational equality and the advantages of incorporation to all congregations free of government interference (Seavoy 1982, p. 3). Laws granting free incorporation to educational and benevolent institutions reflected the leveling and improving spirit of the post-Revolutionary era. The principal advantage of incorporation for a church, educational institution, or charity was that the institution could receive bequests and legacies as well as hold and legally defend property 
under joint title in the name of the (changeable) membership rather than holding it in trust.

Incorporation also promised several advantages for business and corporate charters were eagerly sought by business promoters (Seavoy 1982, p. 4). As with nonprofit institutions, incorporation protected the collective ownership of real and personal property, encouraged the accumulation of large pools of capital, limited investor risk in speculative enterprises, and facilitated access to the courts. In New York reserved incorporation for new and large-scale businesses that did not compete with existing proprietorships and partnerships. Incorporation also established a supervisory role for the state. Turnpikes, canals and bridges required special powers, including eminent domain, condemnation and incorporation. Although the electorate looked favorably on such corporations, it also demanded public oversight to ensure that these firms' neither abused their eminent domain powers nor wandered from the approved route. Banks and insurance company charters granted these companies broad powers, but imposed numerous restrictions and often stripped shareholders of limited liability in the event of fraud. Incorporation implied a balancing act. On one hand, it was the state's responsibility to promote the common weal and the corporation was but one means to do so, mostly by promoting charitable and improvement associations (Handlin and Handlin 1947). On the other, promoting the common weal sometimes required caution and restraint. Institutions capable of providing large social benefits were capable of imposing equally impressive costs. It was the state's responsibility to strike the balance.

Like most other states, New York relinquished its control over business incorporation only grudgingly. Although Gunn (1988, p. 49) contends that, between 1790 and 1820, the corporation evolved into "a modern, essentially private, instrument of economic organization," the evolution was slow and fitful. Before 1800 New York chartered just 28 for-profit corporations, including 13 turnpikes, 4 banks, and 3 canals. During the next decade, the state chartered 179 corporations, mostly turnpike, bridge, and water companies (Evans 1948, p. 17). It was only in the years surrounding the War of 1812 that the number of new manufacturing incorporations (153) exceeded the number of newly incorporated public utilities (134). 
Banking and insurance companies never represented more than a small fraction of the total number of incorporations. Twenty-five insurance companies were chartered between 1800 and 1820; just 28 banks received charters in the same period.

Bank chartering in New York became embroiled in partisan politics from the beginning. Early banks, whether in New York or elsewhere, were popularly identified by their founders' political affiliations. New York's first banks were Federalist and Hamiltonian. Although Republicans distrusted economic privilege and financial operations, they set aside their concerns when they observed how banks could be harnessed to advance a political agenda (Alexander 1906, p. 187; Wright 2002). As dispensers of credit, banks favored those to whom they loaned and, if controlled by a political party, a bank could insure that party supporters were disproportionately advantaged. With the excess demand for credit in early America, banks could link economic outcomes to party affiliation without materially sacrificing profits.

Why didn’t frustrated borrowers just change parties? Some undoubtedly did. But in early America, party affiliations among the political and economic elite were publicly known long before banks came into being and changing parties did not erase years of built-up partisan animosities. Even after banking became well established in the antebellum era, party affiliation alone did not guarantee access to bank credit or ownership. Open and dedicated service to the party was required to become a bank insider, something that opportunistic party switchers may have been unwilling to provide.

Because the legislature limited the number of bank charters, a charter was valuable and prospective bankers were willing to pay potentially large sums in return for a license. Allegations of bribery surfaced at least as early as 1804 with the chartering of the Merchants' Bank of New York City when it was disclosed that one state senator has promised shares to two other senators, along with a guarantee that they could sell the shares at a substantial premium after the charter was passed (Knox 1903, p. 397). ${ }^{2}$ Bribery finally became a public issue in 1812. A charter for the Bank of America in New York City was crafted with a proposed

\footnotetext{
${ }^{2}$ Wright (1997) finds evidence that the first bribery accusations surfaced with the charter of the New York State Bank in 1803.
} 
capital of $\$ 6$ million, or six times the size of the then largest bank in the city. Although the petitioners were Federalists, they hired two prominent Republicans - David Thomas of Washington, D.C. and Solomon Southwick of Albany - to lobby a Republican-dominated legislature on their behalf(Alexander 1906, p. 194). Thomas is described as crafty, unscrupulous and ambitious; Southwick as handsome, personable and charming. Their personalities complemented each other well and, together, they became effective lobbyists. But when the petitioners hired several other lobbyists, events spun out of control.

Several charter requests were laid before the legislature in the opening days of the 1812 session and, in his annual address to the legislature in January, Governor Tompkins advised the legislature to be beware of bank promoters who used "intrigue and hollow pretenses" to "corrupt and subdue republican notions" (Lincoln 1909, p. 697). In March Governor Tompkins chose to exercise his constitutional privilege to suspend the Assembly and Senate for sixty days. In his message dismissing the legislators, Tompkins alluded to improper means used in soliciting a bank charter in the previous legislative session and accused four Federalist members of the Assembly and one state Senator of accepting bribes from the Bank of America's lobbyists (Cole 1984, pp. 27-28). He asked the legislative members to return home, consult with their constituents, and reflect on the enormity of their actions (Lincoln 1909, p. 711). Tompkins also instructed the attorney general to investigate. Several agents for the petitioners were indicted for bribery, among them a former clergyman who was eventually sentenced to the state penitentiary. Thomas was accused of liberally spreading the petitioners' money on both sides of the aisle and both Thomas and Southwick were indicted and tried. Both were acquitted, however, when the star witnesses - a state senator and the Speaker of the Assembly - refused to testify. Ultimately, Governor Tompkins' decision to suspend the legislature had no effect. Shortly after it reconvened, both houses approved the Bank of America's charter. Charges of bribery surfaced throughout the 1810s, but none rose to the level of Bank of America scandal.

\subsection{The Albany Regency, the Safety Fund System, and Chartering as Party Discipline}


New York politics between 1810 and 1820 is a tangled tale of a waning Federalist Party and a DemocraticRepublican Party divided into as many as a half-dozen factions, each claiming to represent the true Jeffersonian faith (Countryman 2001, p. 300). Although there were minor ideological squabbles, the party fractured mostly down sectional lines (Kass 1965, p. 110). Even at the time it was recognized that the dominant faction would be the one that provided a leader capable of quieting divisive voices, blunting sectional rivalries, and guiding members to a common purpose. Although DeWitt Clinton was a charismatic visionary who could rally popular support for specific projects, such as the Erie Canal, he was unable to organize supporters into a unified political party. Where Clinton fell short, Martin Van Buren excelled. Van Buren's gift was his ability to transform a loose coalition of sometimes cooperative, often bickering, factions into a powerful, focused and reasonably stable political machine.

Van Buren entered the state senate in 1813 with what a number of historians and biographers generously describe as a pragmatic approach to politics (Cole 1984, pp. 39-51). He rose to prominence in 1817 when, sensing a strong and growing support for the project, he reversed his outspoken opposition to the Erie Canal and delivered a powerful speech in support. ${ }^{3}$ His speech vaulted him into the political leadership and, from this experience, Van Buren learned the value of being on the popular side of an issue. He then built a formidable coalition of Republicans called Bucktails by their friends (so named because each wore a buck's tail on their hats at party conventions) or the Albany Regency by their detractors. ${ }^{4}$

By 1819, Van Buren's Bucktails were already powerful enough to openly challenge Governor Clinton's nominations by the New York Council of Appointment and his Bucktails dominated the 1820

\footnotetext{
${ }^{3}$ Miller (1962, p. 45) argues that Van Buren's decision to block passage of the Erie Canal's chartering act in 1816 as a political ploy. Van Buren asked for additional studies of the canal's routing and prospects because such a massive undertaking required careful and deliberate consideration. In the 1817 session, Van Buren could then steal Clinton's thunder by arguing that he was as supportive of the project as the others, but more cautious, scrupulous and fiscally responsible than his rivals.

${ }^{4}$ Though the Revolutionary generation had largely passed from power by this time, labeling one's opponent a "monarchist" was still an effective political strategy. Thus by referring to Van Buren's small circle of Republican (upper-case R) leaders as Regents, opponents tarred them with the brush of anti-republicanism (lower-case r). Eventually, the tar stuck and the electorate turned against rule by what was commonly perceived as the Regency elite
} 
legislative elections. ${ }^{5}$ Clinton was reelected governor, but he was surrounded by Bucktails who controlled the Council of Appointment and swept the state's appointive offices of Clinton supporters, replacing them with Bucktail men. Van Buren favored young men on the rise and his political appointees formed the nucleus of New York's Republican Party through the 1830s. By 1823 the Regency was a well-entrenched, wellorganized, smoothly operating political machine -- the pride of its supporters, the envy of its rivals, and the prototypical machine for the next century (Cole 1984, p. 86).

Policy was developed by a small group of men who argued among themselves privately, but never squabbled publicly. Orders from the leadership were transmitted to the legislative party caucus in Albany and disseminated through the hinterlands by the party press, including the highly influential Albany Argus, and by appointed judges as they rode their circuits (Cole 1984, pp. 86-87; Countryman 2001, pp. 300-2). At the grassroots level, the Regency controlled the appointment of thousands of justices of the peace, county judges, and examiners of chancery, who were all expected to further the party's agenda. Failure to do so resulted in the individual's dismissal from his patronage office. Although its control was never absolute, the Regency was so effective that contemporaries commented on "the perfection of Mr. Van Buren's party discipline" (Cole 1984, p. 155).

Charges of corruption swirled around nearly every bank charter introduced between 1813 and 1821 . In an attempt to mitigate corruption, the state constitution of 1821 required a two-thirds majority of both houses to incorporate a bank. Supporters of this measure argued that the super-majority requirement would lead to only truly meritorious bankers receiving corporate privileges (Seavoy 1982, p. 128). Critics argued that the super-majority requirement simply raised the stakes. If more votes were needed, more legislators would have to be persuaded, through whatever means. Whatever its effect on bribery, the two-thirds requirement effect on the growth of banking was clear. Only 12 new banks were chartered between 1821 and

\footnotetext{
${ }^{5}$ Under New York's 1777 constitution, the Council of Appointment was composed of the governor and four state senators that, by 1821 , appointed nearly 15,000 local and state administrative positions, including sheriffs, county clerks, city mayors, justices of the peace, and all state officers except the treasurer who was appointed by the legislature.
} 
1828 , with no new banks chartered in $1822,1826,1827$, or 1828 . At the end of 1828 , crisis loomed for the state's banking system. Table 1 reveals that with less than $\$ 9$ in authorized bank capital per capita New York was less financially developed than Massachusetts (about \$28 per capita) or Pennsylvania (about $\$ 12$ per capita). ${ }^{6}$ Moreover, the charters of 30 of the 40 then operating banks were due to expire during the next five years (Root 1895, p. 288). If these banks' charters expired and the banks wound up without new ones to replace them, New York would be without a legitimate financial sector and the Republicans would have failed in their obligation to promote the commonweal.

The newly elected governor, Martin Van Buren, sought a solution to the banking problem that could simultaneously address three issues. First, it needed to eliminate the chartering logjam created by the twothirds majority mandated by the 1821 constitution for all bank charters. Second, it needed to protect the public against payments system collapses. Third, chartering needed to remain under the Regency's control. Resolving the second issue would resolve the first. Recall that one purpose of restrictive incorporation (legislative chartering) was that the legislature owed a duty to the public to protect it from reckless, irresponsible or excessively risky projectors. But because bankers received charters more for their ability to subvert the political process than for their business acumen (though the two need not have been mutually exclusive) cautious legislators were reluctant to issue charters and set potentially bad bankers loose on an unsuspecting public. Finally, Van Buren needed to bend banking policy to his will. So long as the Bucktail Democrats could retain control of issuing charters, loyal party members would be rewarded with lucrative interests in the banks.

Van Buren's solution was the 1829 Safety Fund Act. ${ }^{7}$ The act required all subsequently chartered

\footnotetext{
${ }^{6}$ Table 1 reports authorized bank capital per capita because these data are available for the entire period. Using data for loans per capita or total bank assets per capita for 1820 and after (when these data become reasonably reliable) does not appreciably alter the main conclusions. Massachusetts remains the most financially developed state, Pennsylvania lags far behind, and New York is an intermediate case. In 1830, for instance, bank loans per capita in Massachusetts were \$45.85; in New York, \$18.23; and in Pennsylvania \$14.25. Safety Fund.

${ }^{7}$ See Calomiris (1989)and Bodenhorn (2003) and sources therein for descriptions and analyses of the
} 
banks, whether their charters were de novo or renewed, to contribute an amount equal to six percent of their paid-in capital to a fund that would reimburse noteholders and depositors of any failing member bank. The act also laid down common charter conditions and established one of the first banking oversight bureaucracies in the nation.

The act engendered broad support, mostly because it overcame legislative reluctance to charter banks. Between 1821 and 1828, New York legislators chartered just 12 banks, only 10 of which opened (Fenstermaker 1965). Passage of the Safety Fund opened the floodgates. Eleven de novo charters were issued in 1829 alone; 9 more in 1830; 9 more again in 1831; 7 in 1832; 8 in 1833; 8 in 1834; and 12 in 1836. Despite the rash of new bank charters, New York remained woefully financially underdeveloped compared to its nearest commercial rivals (see Table 1).

Passage of the Safety Fund, with its protection for the public, pushed questions about the capabilities of prospective bankers who received charters less for their business acumen than for their ability to bribe and corrupt the system to the background. Previously, many legislators voted against all charters afraid that they might unleash a bad bank on an unwary public. By making the banks mutually responsible for one another's debts, the act relieved concerns about the capabilities or actions of any single banker. Under the co-insurance scheme, the costs of bad banking would fall primarily on the banks rather than the public. With fewer concerns about bank quality, legislators could focus on quantity. In short, the insurance guarantee calmed legislators' fears and they chartered more banks - 64 de novo charters and 29 recharters between 1829 and 1836 (Root 1895, pp. 290-91).

The Safety Fund system, however, did not eliminate corruption. One contemporary contended that "lobby men" still engaged in their "mercenary employment[s]" and The Albany Evening Journal (hereafter $A E J)$, an anti-Regency newspaper, published numerous allegations of legislative bribery (Johnson 1850, p. 611). On 13 April, for example, the $A E J$ reported that the Chemical Bank's charter passed after a long delay and "with the loss of the reputation of a Senator." In March 1833 Alvah Bebee was indicted for bribing state 
assemblyman John De Mott. During a legislative hearing, Bebee's attorney argued that his client was being unfairly singled out. He had knowledge of comparable cases in which "members of the Legislature had received stock in banks, for charters on which they had voted, and there had been no concealment in those cases - no sense of impropriety" (AEJ, 21 February 1831). Indeed, Erastus Root, who served in the state assembly between 1798 and 1830, claimed that "no one would hesitate, from motives of delicacy, to offer a member [gratis] shares in a [proposed] bank" (Alexander 1906, p. 190). After a brief debate, the House reprimanded Bebee in a "forcible and solemn manner" and sent him on his way. ${ }^{8}$

Statistics reported in Table 2 provide some appreciation for the potential scale for corruption and bribery. Between 1830 and 1837, the New York State Assembly received 535 petitions, each one praying for a charter from a group of would-be bankers. From those 535 petitions, Assembly committees drafted and reported 236 separate chartering bills for debate on the floor. Of those 236 bills, 134 eventually passed. Of those, only 53, or less than half, later passed the Senate. While citizens could freely petition the legislature, getting the eight members of the Assembly banking committee to take notice of any one petition, turn it into a bill and report it to the floor demanded something notable or especially meritorious on the part of the petitioners. It was common for petitions to be delivered in person by groups of "interested citizens." In most instances how those citizens' interests were expressed is left to the imagination because even contemporary critics generally did not report details of the bribes. In those few instances where the details became public, the most common form of a bribe was a promise of a handful free shares in the proposed bank should the charter pass (Hammond 1852, p. 334; Seavoy 1982, p. 84). Given the low probability of receiving a charter

\footnotetext{
${ }^{8}$ Bebee's comments about members receiving shares in banks whose charters they had voted on stand in contrast to the $A E J$ 's recurring complaints about legislators purposely excusing themselves from votes on some bank charters. Excusing one's self from a vote was an odd strategy for a legislator with a personal financial stake in the outcome, but there was a law prohibiting lawmakers from voting on incorporation acts in which they had a personal interest. Legislators who had been given or promised shares were under a legal obligation to excuse themselves. Of course, it does not mean that they did not influence the outcome through vote trading or other forms of logrolling. In reading the biographies of several members of the Regency, these men did not think it morally contradictory to accept shares in return for legislative influence but then scrupulously adhere to the letter of the law concerning voting rules. It was also not uncommon to draw a distinction between cash payments (bribes) and promises of shares (not bribes). It seems that the risks assumed in holding shares, compared to the certainty of taking cash, led some legislators to believe that they were fundamentally different transactions.
} 
ash payments were less common. Promises of shares aligned the legislators' and the promoters' incentives. ${ }^{9}$

What is notable about the Regency leaders is that they channeled this corruption to the party's benefit rather than their own ends. Although the party's leaders did not line their own pockets, they made it possible for others to line theirs. The Regency's dominance, as Cole (1984, p. 95) notes, was based on the spoils system. Its leaders realized that political machinery was fueled with money and jobs and they distributed both to their friends and supporters. The Regency aligned banks and party through the distribution of equity shares in newly chartered banks.

Beginning in 1811, every incorporation act appointed administrators charged with distributing shares in the new bank. The issue of how shares were allocated gained popular attention in 1825 when the opposition party press publicized the distribution of the Commercial Bank of Albany's initial public offering. The men appointed to distribute the stock allocated most of the shares to themselves and a handful of friends. Political opponents contended that the administrators "had converted a matter of general interest into an affair of individual profit and speculation" (Chaddock 1910, p. 252). ${ }^{10}$ During debate on the charter of the Bank of Herkimer County, Assemblyman Isaac Van Duzer of Orange County offered an amendment reducing the

\footnotetext{
${ }^{9}$ Calculating the economic costs of the distortions engendered by this rent seeking is beyond the scope of this paper, but the potential costs of rent seeking are widely recognized (Murphy, Shleifer, and Vishny 1993). It is also notable that New York received substantially less revenue, as a percent of all state tax revenue, from bank dividends and taxes than any other state. Revenues from banks in New York exceeded 10 percent of state revenues in only one decade, whereas they made up about one-fifth of average state revenues in the antebellum era (Sylla, Legler and Wallis 1987, pp. 400-1). New York's relatively low tax yield from banks was due to the state's relative financial underdevelopment. It may also have resulted from the policy of granting charters to party members who resisted returning those rents to the state in the form of taxes. Small distributional coalitions, as Olson (1965) shows, will be more effective lobbyists than large groups. Because banks were few, shares closely held, and managed by party favorites, the Regency-controlled legislature may have been reluctant to impose substantial taxes.

${ }^{10}$ Limiting share ownership to a group of party friends and loyalists created potentially sharp distributional effects. Lamoreaux (1994) shows that many New England banks were insider affairs, wherein shareholders received the majority of their bank's loans. To the extent that New York banks were similarly insider institutions, non-party members were effectively denied access to credit (assuming that the demand for credit exceeded the supply and banks rationed credit based on party affiliation, which is consistent with even a casual reading of the contemporary and historical literature). The existence of a secondary market for shares, even if it was not particularly liquid, could mitigate this effect. If non-party members were willing to pay more for credit than party members, they could buy shares and become insiders and have preferential access to credit. In this case, existing credit was (reasonably) optimally allocated, but a wealth transfer from non-party members to party members occurred. It does not, however, imply that the existing volume of available credit was socially optimal.
} 
number of shares that the administrators could subscribe from 200 to 50 . The amendment was soundly defeated, at which time Van Duzer exclaimed on the floor that the "Regency manifested no disposition to surrender the source of "Spoils"” (AEJ, 4 February 1833).

It was 1837 before these distribution practices were changed. Twelve banks were chartered in 1836 and the distribution of stock in these banks was so partisan that even the Regency-appointed bank commissioners criticized the abuses in their annual report to the state assembly. The commissioners provided the details of the distribution of shares in the Jefferson County Bank of Watertown. Nine appointed administrators kept the subscription books open for two days, receiving 500 individual subscriptions for varying numbers of shares. Because the offering was oversubscribed, as nearly all new bank offerings were, the administrators had to develop a distribution scheme. Although the administrative panel was bipartisan, the Bucktails held a five to four majority and their distribution plan was adopted. Through proxies and powers of attorney the bank's 12,000 shares were effectively divided between the nine administrators, who each took his legal limit of 250 shares, and seven other men who between them took 7,695 shares. At the time of the investigation, all 12,000 shares were held by just 36 men when 500 had subscribed. ${ }^{11}$ The report suggested that the Jefferson County Bank case was typical. It represented one of the many ways the Bucktails encouraged and rewarded party loyalty.

If the number of editorials appearing in the opposition press (the Albany Evening Journal was the most prominent) is a fair measure, by 1837 the public's tolerance for spoils, especially in connection to bank chartering, was waning. Flagrantly inequitable practices had fallen from favor and the legislature moved to correct them in response to growing public dissatisfaction. An 1837 act dictated that shares were to be sold at public auction. No individual was allowed to buy more than five shares on the first day of the auction, nor more than ten on the second or thereafter. In an effort to guarantee local ownership, buyers had to be residents

\footnotetext{
${ }^{11}$ There was no formal secondary market in country bank shares so that shares traded informally and price information was not made public. Nevertheless, the market value of the Regency's share giveaway were surely substantial. City bank shares regularly traded at prices 25 to 30 percent above par.
} 
of the bank's home county. To head off speculation, shares could not be sold until three months after the entire capital had been raised. All transfers within the first year had to be accompanied by an oath that the seller was the bona fide owner and had not contracted to sell the shares prior to the initial auction. Ultimately, the law was a dead letter because New York's legislature never issued another bank charter.

After more than a decade of debate, New York passed the Free Banking Act of 1838. In 1825 and 1828 special legislative commissions had studied comparable proposals, but had rejected them. Indeed, the initial 1828 Safety Fund proposal (adopted in 1829) included some features of the 1838 free banking act, namely free entry and bond-secured note issue, but they were removed in favor of continued legislative chartering and regulatory oversight. By the mid-1830s, however, appeals to equal rights were commonplace and all state-sanctioned economic advantages were attacked from all sides as usurpations of the true spirit of representative democracy and laissez-faire economics. Capitalizing on the electorate's growing frustration with Regency spoils and a financial panic in 1837, the Whigs wrested control of the state legislature from the Democrats in the autumn 1837 elections. In the opening days of the 1838 legislative session, a senate committee was established to study the appropriateness of rewriting the banking laws to allow free entry of private bankers and reform the system of chartering commercial banks. The committee reported back that the time had come to replace the current chartering system, which was "utterly at war with equal rights and free government" (New York Senate 1838, p. 4). As the end of the legislative term loomed, a free banking act was hammered out and passed in April. New York's free banking act, however, represented neither the inception nor the culmination of the electorate's backlash against state-supported economic privilege. It was not, as Redlich (1968) argued, incipient populism run amok. It was one step, albeit an important one, in New York's movement toward greater political representation and economic liberty.

\section{Free Banking as Reform}

Writing in the Regency-controlled Albany Argus in December 1836, New York State Comptroller Azariah 
Flagg announced the party's new position. "The law as it now exists," he wrote, "abridges the fair business rights of individuals, discountenances the free use of capital, and it detrimental to trade and commerce" (Flagg 1868, p. 8). To have Flagg, a high-ranking Regency official, publish such a statement in the official party newspaper represented an announcement roughly comparable to, say, Harry Truman publicly announcing in 1936 that the Democratic leadership considered the Wagner Act an unconstitutional restraint of trade. It signaled a widening cleavage within the party that was increasingly reflected among the leadership.

Indeed, abuses like those surrounding the distribution of stock in 1836 had created fault lines within New York's Democratic Party. Churchill C. Cambreleng, Van Buren's trusted lieutenant in the U.S. House of Representatives, wrote Van Buren condemning the Regency's banking policy (Seavoy 1982, p. 129). How and why had the Regency's leadership changed their views? Why were they willing to abandon the Safety Fund, often held up as one of their principal legislative achievements, after just nine years? Was it, as Hammond (1957), Redlich (1968), Dowd (1992) and others contend, that the corruption involved in securing a bank charter and distributing shares had finally grown so politically indefensible or so socially costly that the entire structure was thrown over? It turns out that the causes were complex. While corrupt practices in the 1830 s certainly played a role, free banking's origins date back a decade or more and represent not the culmination, but one leg of a long passage wrought by changing attitudes among the electorate, changes the Bucktails embraced only when they could no longer resist them and remain politically viable. A growing debate in New York over the extent of political participation and the extension of the franchise carried over into a parallel debate about the appropriate boundaries of economic freedom. Banking policy represented the ground where these concurrent struggles converged.

\subsection{Setting the Stage for Free Banking}

Free banking did not emerge in 1838 without cause or precedent. Neither was it culmination of an agrarian 
populism as others, including Redlich (1968), contend. It was indicative of a broader push toward greater political and economic freedom occurring in states throughout the United States. In New York constitutional reform in 1821 extended the franchise and eliminated two principal sources of political and administrative centralization, the Councils of Revision and Appointment. The Council of Revision retained veto power over all legislation; the Council of Appointment made appointments to most municipal offices, including justices of peace, sheriffs and mayors, and formed the basis of the Bucktail's spoils system. The constitutional reforms, resisted by the political elite for more than 20 years, conceded greater political determination to the electorate through greater local representation.

Popular demands for greater political liberty led naturally to calls for greater freedom of economic association. New York, it will be recalled, conceded greater freedom of association in religious, educational and charitable institutions early in the century by instituting general incorporation laws for these institutions, but the state closely guarded its chartering privilege for business incorporation. As the economy developed in the northeastern United States and profitability, even in agriculture, became more dependent on access to credit and transportation - to markets generally - the notion that incorporation could be reserved for the few became increasingly indefensible (Handlin and Handlin 1947, p. 113).

Several New England states liberalized incorporation in the early nineteenth century, but in New York the Bucktails retained control to bend incorporation to the party's will. The original 1828 Safety Fund proposal, in fact, included free incorporation and bond-secured note issue - the defining features of free banking - but Van Buren rejected these aspects of the original proposal because the party would have lost an important element of its spoils system. Even in 1838, when Governor William L. Marcy, one of Van Buren's lieutenants, signed the free banking act, he did so reluctantly mostly because the free incorporation clause stripped the party of one of its more important, and lucrative, powers. During the decade between 1828 and 1838, however, public opinion had turned strongly against the status quo. The state had long since ceded freedom of association for religious, educational and charitable associations. It had long been asked to extend 
the privilege of corporate freedom of association business corporations. It finally relented in 1838 .

\subsection{The Antimasons and Political Reform}

The ultimate cause for banking reform can be traced to a long-simmering demand for greater economic freedom, but one of the more important proximate influences and one that brought the demand to a boil was an unlikely event - the disappearance on the night of 14 September 1826 of William Morgan, an unremarkable stonemason and Freemason of Batavia, Genesee County, New York. In the 1820s, Freemasonry was popular. From just 347 lodges and 16,000 members nationally in 1800, there were 450 lodges and more than 20,000 members in New York state alone in 1825 (Formisano and Kutolowski 1977). Disaffected and nearly broke, Morgan threatened to publish Freemasonry's secrets. Local Masons, outraged by Morgan's betrayal, burned David Miller's printing shop and had both men arrested on trumped-up charges. Both were released from jail, but Morgan was kidnaped and never seen again. Rumor had it that a group of Freemasons spirited Morgan off to Fort Niagara where he was briefly detained before being taken into Lake Erie, thrown overboard and, presumably, drowned.

Investigations into Morgan's disappearance implicated a number of prominent Masons who were politically connected members of the Regency. Sheriffs initially refused to arrest them. When they were arrested, prosecutors refused to bring charges. When forced by popular outcry to bring the conspirators to trial, the tribunals quickly became theater, attracting hundreds of spectators. Newspapers published verbatim transcripts, and news spread by word of mouth. For more than four years, the public devoured the news, most of which demonstrated Freemasonry's (and by association, they Regency's) subversion of the political and judicial system. When most of the alleged conspirators were acquitted, a "firestorm of popular protest" was unleashed that grew into a legitimate political movement (Gunn 2001, p. 374). One contemporary book concluded that the abduction, murder and cover-up was the work of hundreds of men, including prominent legislators, lawyers and sheriffs. Special prosecutors appointed by the legislature reported on Masonic 
obstructionism and concluded that the basic charges of conspiracy, kidnaping, and murder were true.

Antimasonry's appeal and, therefore, its political legitimacy grew because reasonable men believed that Freemasonry disproportionately influenced the administration of justice (Vaughn 1983). Several sheriffs, prosecutors, judges, and other officials involved in the investigation and prosecution of the crime were Masons. Most discharged their duties fairly and impartially, but others manipulated the system to protect fellow Masons. Formisano and Kutolowski (1977, p. 153) conclude that a widespread conviction that there had been "a systematic corruption of justice ... was far from fantastic." Building a platform on equality before the law, the Antimason Party quickly emerged as a viable political force. The hot-button issues in the 1828 New York election were less the burning national issues of states' rights and internal improvements than the candidates' characters, Antimasonry, and whether it was time for special privilege to give way to the popular will. Andrew Jackson polled an unimpressive 51 percent in New York; Van Buren won the governorship, but only because two opponents, including Solomon Southwick, the Antimason candidate, split the opposition vote (Benson 1961, p.31). ${ }^{12}$

Antimasonry's consequences were profound. The number of Masonic lodges in New York fell from 490 to 80 and active membership declined from 20,000 to just 3,000 (Benson 1961, p. 36). Once it had crushed its principal opponent, neither the movement nor the Antimasonic Party petered out. An effective leadership with access to more than 45 newspapers expanded the message. Privilege subverted more than criminal justice. Privileged and secretive organizations of all types, including politically favored corporations, subverted all forms of republican virtue. Equality before the law, equality of representation, and equality of opportunity became the party's watchwords. Antimasonry was radical populism. One speaker at the 1829 Antimason convention insisted that "public opinion ... must properly govern everything, which is properly subject to governmental power" (quoted in Benson 1961, p. 22). The party's message appealed to a leveling impulse: universal male suffrage; universal state-supported education; antislavery; and better treatment of

\footnotetext{
${ }^{12}$ We met Solomon Southwick before. He was one of the prominent lobbyists in the 1812 Bank of America chartering scandal.
} 
Indians, orphans, and the mentally ill (Van Deusen 1944).

Antimason calls for reform quickly incorporated the hot-button economic issues. The party favored strict enforcement of usury laws, elimination of imprisonment for debt, expanding the transportation network and, of course, greater sectional equality in the distribution of banking and financial services. Early histories of Antimasonry argued that it was motivated by rural-agrarian jealousies of urban commercial wealth and power. The reality was more complex. Table 3 reports bank capital per capita by senate district at selected dates between 1830 and $1857 .{ }^{13}$ Not surprisingly, New York City outstripped all other regions, with Albany a distant second. But even outside the two principal urban-commercial areas, there were sharp disparities in the distribution of bank capital. The Adirondack/Lake Champlain region (IV) had just $\$ 0.45$ in per capita bank capital, while the Finger Lakes region had \$5.66 The eight-region Gini Index for 1830 is 0.69 , implying substantial inequalities. Moreover, in 1830 fully two-thirds of all New York counties were without a bank.

Passage of the Safety Fund, and the increased chartering that accompanied it, led to more equally distributed per capita bank capital. Even the relatively underdeveloped Adirondack/Lake Champlain region witnessed a 662.2 percent increase in per capita bank capital between 1830 and 1837, as per capita bank capital increased from $\$ 0.45$ to $\$ 3.43$. The Gini Index declined to 0.48 and the number of counties without a bank declined sharply. It took free banking and a long period of economic prosperity (1845-1857) to bring about greater equality of per capita banking capital and to provide nearly every county with at least one commercial bank. By the mid-1850s, every Senate District attained double-digit per capita bank capital and only 3 counties (5.2\%) remained without a commercial bank. By 1850, too, the Gini Index declined to 0.36 and remained steady throughout the decade.

Rural-agrarian jealousy about greater urban access to credit was one of many factors driving the discontent in western New York (Redlich 1968). Yet complaints did not necessarily originate among cash-

\footnotetext{
13 The dates were chosen to control for broad macroeconomic events to the extent possible. The 1830s and 1850s were both periods of relative early prosperity followed by sharp financial panics in 1837 and 1857 .
} 
strapped, credit-constrained farmers. The sources of discontent were more complex. Kutolowski (1984) and Formisano (1993) argue that Antimasonry cut across economic classes. Indeed, Kutolowski (1984) argues that support for Antimasonry was stronger in townships with more improved acreage, higher population densities, and higher values per acre. Antimasonry's leaders were mostly drawn from the middling to upper classes of western and southern New York - regions where the transportation and financial revolutions had not yet fully arrived. The Antimason challenge was elementary, if somewhat naive: Should not all men living in a democratic society have equal access to the opportunities offered by a rapidly expanding economy? Was it fair that the Masonic-dominated Regency granted unfair advantages in the race for wealth and prestige? In this respect, the movement appealed most strongly to those eager to "utilize participant politics to gain further transportation improvements, banking facilities, and ... favorable local public policy" (Kutolowski 1984, p. 281). Antimasonry flourished where the market had brought some limited prosperity. Its leaders wanted greater access to wealth-generating technologies - banks, canals, railroads - controlled by the Regency.

It was some time before the egalitarian impulse was translated into specific policies, such as free banking (Benson 1961, p. 37), but the movement gained momentum in the 1830s. In 1831, imprisonment for debt was abolished. The state expanded funding for education. Feeder canals were proposed, surveys done, and construction begun. Calls for the elimination of restraining laws on private banking reemerged in 1835 and 1836. Free banking was seriously debated in both houses of the legislature in 1837 , just as a movement for a new constitutional convention took shape. The Utica Convention of 1837 proposed a constitutional amendment prohibiting future legislatures from passing laws that favored one group over another (Gunn 1988, p. 172). The convention delegates called for the abolition of legislative chartering in all forms, tighter restrictions on the state's ability to issue debt, and the elimination of all regulations restricting entry into any profession or occupation.

By 1837, legislative debates on banking policy were unmistakably Antimasonic. In condemning the assembly's committee on banks' decision not to report a bill for a bank, Assemblyman John Wilkinson of 
Onondaga County fumed that "the citizens of New York [City] cannot, without arrogance, assume to judge the propriety of incorporating a bank at Utica" (AEJ, 22 March 1836). That decision was best left to the citizens of Utica. A group of citizens in Albion forwarded a petition to the legislature stating that "the people are coming ... the spirit of reform is awake throughout the State" (AEJ, 28 March 1837). Indeed, the reform spirit had grown so strong that Regency governor William L. Marcy, in his annual message to the legislature, urged reform. The current system was "unquestionably injurious," and it was "the essential characteristic of private property, that the owner should not only have the right of exclusive possession, but the liberty of free use" (AEJ, 3 January 1837). Marcy's position, insofar as it dealt with banking, represented a significant liberalization of Regency attitude and policy.

Antimasonry demonstrates the sometimes serendipitous nature of economic reform; namely, how it can be dependent on events seemingly far removed from the underlying issue. Could those Masons who tossed William Morgan overboard have had any idea that they would unleash a political movement that would shake Masonry and the Regency to their foundations? Could they have contemplated the notion that the events they would unleash would result in rewriting the contract between the state and the business community? Of course not. This is not to argue that free banking depended on William Morgan's unsolved disappearance. Something akin to it had been proposed, but rejected as politically unpalatable, in 1828, a halfdecade prior to the establishment of the Antimasonic Party. It does argue, however, that a seemingly unrelated, random event can bring a latent demand for change to the fore. In this case, it led to the formation of an opposition political party that tapped into that latent demand, sharpened its focus, and made it a prominent element of the party's platform.

\subsection{The Confluence of Party Rhetoric and Political Change in the Mid-1830s}

Regency support for free banking became official policy only when the reform impulse was so far beyond their control that support for the repeal of the Safety Fund system came from a Democratic splinter group 
known as the Loco-Focos (or, sometimes, the Equal Rights Party). These were mostly tradesmen and small entrepreneurs in New York City who believed that the current system threatened their economic well-being. They believed that economic independence was based on property ownership. Any government that passed laws that favored accumulation by the few, as the Safety Fund did, was bad government. "A viable urbanindustrial democracy required that opportunities for business profits had to be equalized" (Seavoy 1982, p. 130). And more than anything else, equality of opportunity implied equality of access to bank credit. An elimination of chartered commercial banking and its replacement with private banking was the best means to achieve this end.

Likewise, Jacksonian Democrats were driven by a strong egalitarian impulse (Schlesinger 1945; Sellers 1991). Jefferson's Republicanism had extended equality of opportunity to the yeomanry in the newly settled West. Banking policy in the early West was both inflationary and developmental (Bodenhorn 2003). States such as Kentucky, Tennessee, and Illinois, among others, established wholly state-owned banks to provide medium-term mortgage credit to farmers wanting to buy land. As a result, migrants flowed in, bought up land and, in a brief period, turned a frontier into a thriving agricultural community. As the Jacksonians saw it, something similar was needed to stem the rising tide of economic inequality in the emergent urbanindustrial regions of the East. ${ }^{14}$

Free banking aligned Antimasons, Jacksonians, and the Loco-Focos. Loco-Foco calls for equality of opportunity appealed to the Jacksonians' sense of fair play. The nagging issue for banking policy, however, was how to simultaneously equalize opportunity and provide a safe, redeemable currency. Two bills

\footnotetext{
${ }^{14}$ Such a brief description of Jacksonian policy necessarily hides the many contradictions that permeated Jackson's Democratic Party. The charismatic Jackson assembled a coalition of pro-bank and anti-bank men, rural agrarians and urban mechanics, ardent supporters of federally supported internal improvements and those equally ardently opposed to such expansion of federal intervention, as well as former Federalists and old Republicans. Thus, a cornerstone of Jacksonian Democracy was a deep antagonism toward banks. But it was also a party supportive of entrepreneurship and enterprise. Even Jackson's veto of the Second Bank's recharter did not "clarify the party's stance and future relationship with the hundreds of other banks in the country" (Sharp 1970, p. 5). Some Jacksonians sought to make banks safer so that more could be chartered. Others sought the complete abolishment of banking. The latter contributed the lasting party rhetoric, but the former, ultimately, had a greater influence on policy, as free banking in New York and elsewhere testifies.
} 
introduced in the 1837 session skirted the issue. One bill would have repealed most of the 1804 restraining act that prohibited unincorporated firms from engaging in any banking functions. It would have allowed for the creation of limited-liability partnerships granting unincorporated associations of individuals the right to engage in all pertinent banking functions, except the circulation of notes ( $A E J, 18 \mathrm{March} 1837)$. The second bill would have created unincorporated banks with all the privileges of banks, including note issue, but these banks would not be allowed to circulate notes under \$20 (AEJ, 3 March 1837). Both bills protected the public from bad banking by limiting their ability to interact with the public. Deposit banking was not yet widespread except among merchants and few people engaged in routine transactions had much use for $\$ 20$ or greater notes. Neither bill passed the state Senate, largely because the attorney general believed that they were both unconstitutional because they would have created de facto corporations in violation of the constitutional twothirds requirement. In the end, the legislature rolled back certain features of the restraining act so that brokers could engage in some limited private banking functions (Seavoy 1982, p. 150).

Before the autumn elections, panic swept the nation's financial markets. Banks suspended specie payments and Whigs soundly defeated the Bucktails at the polls. Whigs interpreted their victory as a mandate to dismantle the Safety Fund and many traveled to Albany intent to pass a general incorporation law. Although William L. Marcy, the Bucktail governor, publicly recommended passage of a free banking law, he remained privately opposed. He understood that a general incorporation law would undermine the party's stranglehold on an important source of patronage. Moreover, it might threaten the stability of the Safety Fund system itself. Seavoy (1982, p. 152) contends, as well, that Van Buren's sub-treasury plan at the federal level - predicated on the idea that the government should separate itself from the business of banking - discredited the Regency's long and close connection with the state's banks. Marcy was forced into a corner and had little choice but to advocate passage of, what he hoped would be, a carefully crafted general incorporation law.

In April 1838, New York enacted free banking. Gunn (1988, p. 229) contends that the law represented "one of the most important pieces of state legislation in the first half of the nineteenth century." 
It reflected a transformation in the role of the legislature in economic matters: a movement away from, but not a complete abandonment of, the commonwealth ideal. Incorporation became a purely administrative function. The legislature relinquished its power to confer privilege to a bureaucracy charged to implement a set of procedures and policies applicable to all. Free banking depoliticized the corporation and reflected the decline of legislative authority in economic matters. The corporation lost its essentially public character and became a purely private matter. It is ironic, however, that although the franchise was substantially widened, free banking and similar measures significantly restricted the electorate's ability to influence social and economic outcomes. Shortly after the public gained a greater say in politics, the polity built firewalls between itself and the economy. It was almost as if the electorate had come to appreciate the efficiency costs of Mancur Olson's (1982) distributional coalitions and did what it could to eliminate some of the costs by taking away at least one mechanism for establishing them.

\subsection{The Consequences of Free Banking}

Much was expected of free banking. A report of the select committee of the Assembly effectively summarizes contemporary expectations for free banking. A general incorporation law would eliminate the

privilege and monopoly associated with the Safety Fund system. It would eliminate one source of legislative corruption and reduce log-rolling. Bank ownership would be more widely dispersed. The banks themselves would be more rationally located. Greater access to credit would encourage commercial and manufacturing. And, finally, it would increase and add stability to the currency.

Two major aspects of free banking are relevant to the issues addressed in this chapter, namely, privilege and greater equality of opportunity, especially among small-scale entrepreneurs. First, free banking replaced special interest legislation with a "rule of law." Relatively inflexible administrative procedures and policies replaced highly idiosyncratic, flexible, personalized charter conditions. Regulators administering rules were less prone to corruption than legislative committees and others given a measure of discretion 
(Glaeser and Shleifer 2003). The administrative policy was clear and precise and less likely to be subverted by legislative or judicial corruption.

Second, free banking reflected the leveling impulse of the Jacksonian era. The 1838 act brought together many of the features of the two 1837 proposals. One would have lifted restraints on individuals and partnerships wanting to operate private banks, and was intended to promote the establishment of relatively small institutions that could respond to and accommodate local needs. The second proposal aimed to replace the current system of chartering relatively large, incorporated, commercial banks. The final 1838 act included both features in that it established one standard for larger joint-stock banks and a lesser standard for individual (effectively note-issuing private) banks. Indeed, free banking encouraged small-scale entrepreneurship fully consistent with Antimasonic and Jacksonian, even Jeffersonian, rhetoric. In March 1850, for example, 29 of 47 individual banks had $\$ 20,000$ or less in paid-in capital, and between 1840 and 1850 the capitalization of the average free bank declined from $\$ 263,000$ to $\$ 176,000 .^{15}$

In its encouragement of small business, free banking advocates believed they had simultaneously addressed the issues of corruption, privilege, equality of opportunity, and protection of the public against incompetent bankers through the 100 percent note-collateral provision. Some Jacksonians criticized banks because they believed that banks, and corporations generally, occupied privileged positions, exercised disproportionate economic power, and were capable of doing serious political and economic damage. Antibank Democrats were convinced of the economic damage that could be wrought by banks when, during the Bank War, Nicholas Biddle contracted the Second Bank's credit and threw the economy into recession. If a bank hiccuped and the economy fell into recession, what might happen if one or more large banks failed? What if they aligned themselves in opposition to the common weal? Such questions brought concerns for the safety and security of bank creditors to the forefront. Free banking, it was believed, simultaneously addressed

\footnotetext{
15 The capitalization of the average chartered bank remained constant at about $\$ 375,000$. Banks chartered under the Safety Fund system or earlier were allowed to maintain their charter for the lifetime of the charter (20 years to perpetuity), but were forced to convert to a free banking charter at expiration of their original charter. The last Safety Fund banks switched to free banking charters in the late-1850s.
} 
these multiple concerns. In encouraging small banks, they would not obtain disproportionate political or economic influence, and their ability to inflict losses would be limited.

Although loss rates for failed free banks in the 1840 s were substantial, by the 1850 s the loss rate fell sharply and was well below that experienced by the failures of 11 of the Regency's Safety Fund banks. This reduced loss rate in tandem with a more responsive allocation of bank capital made free banking attractive. Eventually 17 other states passed free banking laws modeled after New York's. Three others significantly liberalized chartering and adopted bond-secured note issue. During the U.S. Civil War, free banking went national; when the national banking system was formed it adopted several features of New York's 1838 law. While Antimasonry was not particularly exportable as the party never became much of a factor outside New York, free banking was eminently exportable. The reform impulse of the Jacksonian era was strong, but translating the latent impulse into specific policies differed from state to state. Investigating the conditions under which free banking was adopted elsewhere would be a potentially fruitful line of future research.

\section{Concluding Remarks}

Free banking was neither Jacksonian laissez faire run amok as Redlich (1968) would have us believe, nor was it a knee-jerk reaction by newly ascendant Whigs looking to tear down a prominent component of the Regency's political machine. It resulted from parallel movements begun in the early nineteenth century that called for greater political and economic self-determination. Changes in New York's constitution in 1821 largely met the former demands, but Van Buren's Regency retained enough control over the distribution of economic privilege, through special incorporation acts for all types of businesses, to fester discontent.

An unlikely event, however, sparked the formation of a rival political party, one committed to economic equality and one with an ability equal to the Regency's to get its message out to the electorate through the partisan press. Thurlow Weed's Albany Evening Journal was an effective counter to the Regency's Albany Argus. Indeed, few weeks passed between 1830 and 1837 when there was not an editorial 
about banking or bank chartering in Weed's Journal. There were an equally small number of weeks in which the Argus dared to discuss the subject. ${ }^{16}$ Apparently, the Regency's official strategy was to ignore Antimasonic attacks on its bank chartering policy. That, in the end, may have been one of the Regency's larger mistakes. It let the opposition define the debate and rarely responded with a defense of its policy. The Regency's silence must have appeared to many contemporaries as conceding the point - that corruption was rampant, that the Democrats were the party of "spoils", and that they had no intention to reform the system. Such sentiments, combined with a common belief that increased access to banks accelerated the rate of capital accumulation and economic growth, spurred a reform impulse to which the Democrats failed to respond. Free banking and, later, general incorporation, was but one consequence of the leveling impulse in New York.

\section{References}

Albany Argus, various issues.

Albany Evening Journal, various issues, 1830-1838.

Alexander, DeAlva Stanwood. A Political History of the State of New York, Vol. I. New York: Henry Holt \& Company, 1906.

Benson, Lee. The Concept of Jacksonian Democracy: New York as Test Case. Princeton: Princeton University Press, 1961.

Benson, Lee and Joel Silby. "Electoral and Demographic Data Set for New York, 1830-1875; Part 6: New York State Election Returns, Censuses, Religious Censuses.” ICPSR Data Set 6926.

Bodenhorn, Howard. A History of Banking in Antebellum America: Financial Markets and Economic Development in an Era of Nation-Building. Cambridge: Cambridge University Press, 2000.

------. State Banking in Early America: A New Economic History.

Bulow, Jeremy I. “Durable-Goods Monopolists.” Journal of Political Economy 90, no. 2 (April 1982), pp. and 1837 .

${ }^{16}$ This observation is based on my reading nearly every issue of each newspaper published between 1830 
314-332.

Calomiris, Charles W. "Deposit Insurance: Lessons from the Record.” Federal Reserve Bank of Chicago Economic Perspectives 13 (May/June 1989), pp. 10-30.

Chaddock, Robert E. The Safety Fund Banking System in New York, 1829-1866. $61^{\text {st }}$ Congress, 2 Session. Senate Document No. 581. National Monetary Commission. Washington, D.C.: Government Printing Office, 1910.

Cole, Donald B. Martin Van Buren and the American Political System. Princeton: Princeton University Press, 1984.

Countryman, Edward. "The Empire State and the Albany Regency.” In The Empire State: A History of New York, pp. 295-304. Edited by Milton M. Klein. Ithaca and London: Cornell University Press, 2001.

Daniels, Belden L. Pennsylvania, Birthplace of Banking. Harrisburg, PA: Pennsylvania Bankers Association, 1976.

Dowd, Kevin. "U.S. Banking in the 'Free Banking Period."' In The Experience of Free Banking, pp. 206240. Edited by Kevin Dowd. London and New York: Routledge, 1992.

Dwyer, Gerald P. Jr. "The Effects of the Banking Acts of 1933 and 1935 on Capital Investment in Commercial Banking.” Journal of Money, Credit, and Banking (May 1981), pp. 192-204.

Economopoulos, Andrew and Heather O’Neill. "Bank Entry during the Antebellum Period." Journal of Money, Credit, and Banking 27, no. 4 (November 1995), pp. 1071-1085.

Evans, George Herberton, Jr. Business Incorporations in the United States, 1800-1943. New York: National Bureau of Economic Research, 1948.

Fenstermaker, J. Van. The Development of American Commercial Banking, 1782-1837. Kent, Ohio: Bureau of Economic and Business Research, Kent State University, 1965.

Flagg, Azariah C. Banks and Banking in the State of New York from the Adoption of the Constitution in 1777 to 1864. Brooklyn, NY: Rome Brothers, 1868. 
Formisano, Ronald P. "The New Political History and the Election of 1840.” Journal of Interdisciplinary History 23, no. 4 (Spring 1993), pp. 661-682.

------ and Kathleen Smith Kutolowski. “Antimasonry and Masonry: The Genesis of Protest, 1826-1827.” American Quarterly 29, no. 2 (Summer 1977), pp. 139-165.

French, J. H. Gazetteer of the State of New York. Tenth Edition. Subscription only, 1861.

Frye, Timothy and Andrei Shleifer. "The Invisible Hand and the Grabbing Hand." American Economic Review Papers and Proceedings 87, no. 2 (May 1997), pp. 354-58.

Gallatin, Albert. Considerations on the Currency and Banking System of the United States. Philadelphia: Carey \& Lea, 1831.

Glaeser, Edward L. and Andrei Shleifer. "The Rise of the Regulatory State.” Working paper, Harvard University, June 2002.

Golembe, Carter H. "The Deposit Insurance Legislation of 1933: An Examination of its Antecedents and Purposes.” Political Science Quarterly 76, no. 2 (June 1960), pp. 181-200.

Greene, William H. Econometric Analysis. New York: Macmillan Publishing Company, 1990.

Grinath, Arthur III, John Joseph Wallis, and Richard Sylla. "Debt, Default, and Revenue Structure: The American State Debt Crisis in the Early 1840s.” NBER working paper H0097, March 1997.

Gunn, L. Ray. The Decline of Authority: Public Economic Policy and Political Development in New York, 1800-1860. Ithaca and London: Cornell University Press, 1988.

-----. "From Factions to Parties: The Emergence of the Second Party System." In The Empire State: A History of New York, pp. 369-382. Edited by Milton M. Klein. Ithaca and London: Cornell University Press, 2001.

Hammond, Bray. Banks and Politics from the Revolution to the Civil War. Princeton, NJ: Princeton University Press, 1957.

Handlin, Oscar and Mary Flug Handlin. Commonwealth: A Study of the Role of Government in the American 
Economy: Massachusetts, 1774-1861. Cambridge, MA: Harvard University Press, 1969.

Horowitz, Morton J. The Transformation of American Law. Cambridge, MA: Harvard University Press, 1977. Hughes, Jonathan. The Governmental Habit Redux: Economic Controls from Colonial Times to the Present. Second edition. Princeton, NJ: Princeton University Press, 1991.

Johnson, A. D. “The Legislative History of Corporations in the State of New York.” Merchants' Magazine and Commercial Review 23 (December 1850), pp. 610-614.

Kass, Alvin. Politics in New York State, 1800-1830. Syracuse: Syracuse University Press, 1965.

King, Robert. “On the Economics of Private Money.” Journal of Monetary Economics 12 (1983), pp. 127-58.

Knox, John Jay. A History of Banking in the United States. New York: Rhodes \& Company, 1903.

Kutolowski, Kathleen Smith. “Antimasonry Reexamined: Social Bases of the Grass-Roots Party.” Journal of American History 71, no. 2 (September 1984), pp. 269-93.

Lamoreaux, Naomi R. Insider Lending: Banks, Personal Connections, and Economic Development in Industrial New England. Cambridge: Cambridge University Press, 1994.

Levine, Ross. "Financial Development and Economic Growth: Views and Agenda." Journal of Economic Literature 35, no. 2 (June 1997), pp. 688-726.

Lincoln, Charles Z (editor). Messages from the Governors, Vol. II. Albany: J. B. Lyon Company, 1909.

Massachusetts. House of Representatives. Abstract from the Returns of Banks in Massachusetts. (Broadside) (August 1829).

Massachusetts. House of Representatives. "Report of the Joint Committee on Banks and Banking." House Document No. 33. House Journal (20 January 1853).

Massachusetts. Senate. “Report of the Joint Committee on Banks and Banking.” Senate Document No. 85. Senate Journal (23 March 1853).

Mauro, Paolo. “Corruption and Growth.” Quarterly Journal of Economics 110, no. 3 (August 1995), pp. 681712. 
Miller, Nathan. The Enterprise of a Free People: Aspects of Economic Development in New York State during the Canal Period, 1792-1838. Ithaca, NY: Cornell University Press, 1962.

Murphy, Kevin M., Andrei Shleifer, and Robert W. Vishny. "Why is Rent-Seeking so Costly to Growth?" American Economic Review Papers and Proceedings 83, no. 2 (May 1993), pp. 409-14. Reprinted in The Grabbing Hand, pp. 81-89. Edited by Andrei Shleifer and Robert W. Vishny. Cambridge, MA: Harvard University Press, 1998.

New York State. Civil List and Forms of Government of the Colony and State of New York. Albany: Weed, Parsons and Company, 1874.

New York State. Assembly. "Report of the Bank Commissioners." Assembly Document No. 59 (25 January 1831).

New York State. Assembly. “Annual Report of the Bank Commissioners.” Assembly Document No. 71 (24 January 1838).

New York State Assembly. “Annual Report of the Superintendent of the Banking Department.” Assembly Document No. 4 (5 January 1858).

New York State Senate. "Report of the Select Committee on the Bill to Repeal the Laws Restraining Private Banking." Senate Document No. 42 (20 February 1838).

Olson, Mancur. The Logic of Collective Action: Public Goods and the Theory of Groups. Cambridge, MA: Harvard University Press, 1965.

------. The Rise and Decline of Nations: Economic Growth, Stagflation, and Social Rigidities. New Haven and London: Yale University Press, 1982.

Peltzman, Sam. "Entry in Commercial Banking." Journal of Law and Economics (October 1965), pp. 11-60.

Pennsylvania. "Tabular Statement of the Resources of Various Banks in Pennsylvania, in the month of November 1857. Legislative Documents. (1857), pp. 202-213.

Pennsylvania. House. "Report of the Committee on Banks.” Report No. 126. House Journal vol. 2 (1832/33). 
Pennsylvania. Senate. "Communication from the Auditor General Accompanied with a Statement of Certain Banks." Senate Journal (1830-31).

Pennsylvania. Senate. Senate Journal (1837-1838), pp. 48-145.

Pennsylvania. Senate. "Tabular Statement of the Condition of the Various Banks of Pennsylvania, for the Month of November, A.D., 1850. Senate Journal. (1851), pp. 372-79.

Redlich, Fritz. The Molding of American Banking: Men and Ideas. New York: Johnson Reprint Company, 1968.

Rockoff, Hugh. “The Free Banking Era: A Reexamination.” Journal of Money, Credit, and Banking 6, no. 2 (May 1974), pp. 141-67.

Root, L. Carroll. "New York Bank Currency: Safety Fund vs. Bond Security.” Sound Currency 2, no. 5 (1 February 1895), pp. 285-308.

Scheiber, Harry N. "Government and the Economy: Studies of the 'Commonwealth' Policy in NineteenthCentury America.” Journal of Interdisciplinary History 3, no. 1 (Summer 1972), pp. 135-51.

Schlesinger, Arthur M., Jr. The Age of Jackson. New York: Book Find Club, 1945.

Schwartz, Anna J. “The Beginning of Competitive Banking in Philadelphia, 1782-1809.” Journal of Political Economy 55, no. 5 (October 1947), pp. 417-431.

Seavoy, Ronald E. The Origins of the American Business Corporation, 1784-1855. Westport, CT: Greenwood Press, 1982.

Sellers, Charles. The Market Revolution: Jacksonian America, 1815-1846. New York and Oxford: Oxford University Pres, 1991.

Shade, William Gerald. Banks or No Banks: The Money Issue in Western Politics, 1832-1865. Detroit: Wayne State University Press, 1972.

Sharp, James Roger. The Jacksonians versus the Banks: Politics in the States after the Panic of 1837. New York and London: Columbia University Press, 1970. 
Shleifer, Andrei and Robert W. Vishny. "Corruption.” Quarterly Journal of Economics 108, no. 3 (August 1993), pp. 599-617. Reprinted in The Grabbing Hand, pp. 91-108. Edited by Andrei Shleifer and Robert W. Vishny. Cambridge, MA: Harvard University Press, 1998.

Sokoloff, Kenneth L. "Inventive Activity in Early Industrial America: Evidence from Patent Records, 17901846.” Journal of Economic History 48, no. 4 (December 1988), pp. 813-850.

Starnes, George T. Sixty Years of Branch Banking in Virginia. New York: Macmillan Company, 1931.

Sylla, Richard. "Early American Banking: The Significance of the Corporate Form." Business and Economic History 14, no. 1 (March 1985), pp. 173-188.

------, John B. Legler, and John J. Wallis. "Banks and State Public Finance in the New Republic: The United States, 1790-1860.” Journal of Economic History 47:2 (June 1987), pp. 391-403.

Tanner, Henry S. A Description of the Canals and Railroads of the United States. New York: T. R. Tanner \& J. Disturnell, 1840. Reprint Edition. New York: Augustus M. Kelley, 1970.

U.S. Department of State. Fourth Census. Census for 1820. Washington, D.C.: Gales \& Seaton, 1821.

U.S. Department of State. Fifth Census. Fifth Census, Or Enumeration of the Inhabitants of the United States. 1830. Washington, D.C.: Duff Green, 1832.

U.S. Department of State. Sixth Census. Sixth Census or Enumeration of the Inhabitants of the United States. Washington, D.C.: Blair \& Rives, 1841.

U.S. Census Office. Seventh Census. The Seventh Census of the United States, 1850. Washington, D.C.: Robert Armstrong, 1853.

U.S. Census Office. Eighth Census. Population of the United States in 1860. Washington, D.C.: Government Printing Office, 1864.

U.S. Census Office. Ninth Census. A Compendium of the the Ninth Census, 1870. Washington, D.C.: Government Printing Office, 1872.

U.S. Comptroller of the Currency. Report of the Comptroller of the Currency. Washington, D.C.: 
Government Printing Office, 1876.

U.S. House of Representatives. $26^{\text {th }}$ Congress, $1^{\text {st }}$ Session. House Executive Document No. 172.

U.S. House of Representatives. 32d Congress, $1^{\text {st }}$ Session. House Executive Document No. 122.

U.S. House of Representative. $35^{\text {th }}$ Congress, $1^{\text {st }}$ Session. House Executive Document No. 107.

Vaughn, William Preston. The Antimasonic Party in the United States, 1826-1843. Lexington, KY: The University of Kentucky Press, 1983.

Van Deusen, Glyndon G. "Thurlow Weed: A Character Study." The American Historical Review 49, no. 3 (April 1944), pp. 427-440.

Williams, Edwin. The New York Annual Register for the Year of Our Lord 1833. New York: Peter Hill, 1833.

-----. The New York Annual Register for the Year of Our Lord 1837. New York: G. \& C. Carvill \& Company, 1837.

-----. The New York Annual Register for the Year of Our Lord 1845. New York: Turner \& Hayden, 1845.

Wright, Robert E. Banking and Politics in New York, 1784-1829. Unpublished Ph.D. dissertation, SUNYBuffalo, 199x.

--------. Hamilton Unbound: Finance and the Creation of the American Republic. Westport, CT: Greenwood Press, 2002. 
Table 1: Bank Capital per Capita in Massachusetts, New York, and Pennsylvania selected dates

\begin{tabular}{llll}
\hline Year & Massachusetts & New York & Pennsylvania \\
1800 & $\$ 9.01^{\mathrm{a}}$ & $\$ 5.81^{\mathrm{b}}$ & $\$ 8.06^{\mathrm{a}}$ \\
1805 & 12.22 & $7.27^{\mathrm{b}}$ & 10.04 \\
1810 & 14.16 & $7.75^{\mathrm{b}}$ & $7.41^{\mathrm{c}, \mathrm{d}}$ \\
1815 & 23.07 & $15.93^{\mathrm{b}}$ & $16.38^{\mathrm{d}}$ \\
1820 & 20.26 & $15.38^{\mathrm{b}, \mathrm{e}}$ & $14.02^{\mathrm{d}, \mathrm{f}}$ \\
1825 & 25.74 & $16.04^{\mathrm{b}}$ & $\mathrm{na}^{\mathrm{f}}$ \\
1830 & 31.61 & $12.44^{\mathrm{b}, \mathrm{e}}$ & $10.84^{\mathrm{d}, \mathrm{f}}$ \\
1835 & 45.36 & $14.72^{\mathrm{b}, \mathrm{g}}$ & $11.65^{\mathrm{f}}$ \\
$1837^{*}$ & 54.99 & $16.43^{\mathrm{h}}$ & 14.86 \\
1840 & 45.75 & 15.15 & 14.04 \\
1845 & 36.24 & 15.94 & 7.32 \\
1850 & 37.13 & 15.29 & 7.43 \\
1855 & 53.05 & 24.19 & 7.67 \\
1860 & 54.00 & 28.72 & 8.80 \\
& & & \\
\hline
\end{tabular}

Notes and Sources: Unless otherwise noted, estimates are based on capital accounts reported in U.S. Comptroller (1876) and U.S. Census Office (1872). Population estimates for noncensus years calculated from continuously compounded growth rates between census years.

* Last year of legislative bank chartering in New York State.

${ }^{a}$ Estimates are for 1801.

${ }^{\mathrm{b}}$ Bank capital from Williams (1837, p. 235). Gallatin's (1831, pp. 97-103) imply slightly different figures: $1811, \$ 7.57 ; 1815, \$ 16.57 ; 1820, \$ 13.83 ; 1830, \$ 12.78$.

${ }^{\mathrm{c}}$ Estimate for 1811.

${ }^{\mathrm{d}}$ Estimates from Gallatin (1831, pp. 97-103).

e Fenstermaker's (1965) reports for capital imply different figures: 1819, \$0.84; 1830, \$3.54.

${ }^{\mathrm{f}}$ Fenstermaker's (1965) reports for capital yield different figures: 1820, $\$ 6.37 ; 1825, \$ 7.57 ; 1830, \$ 9.51$; $1835, \$ 12.39$.

g U.S. Comptroller's (1876, p. CIII) figure implies $\$ 14.14$

${ }^{\text {h }}$ Fenstermaker's (1965) figure implies \$16.21. 
Table 2

Petitions Received, Bills Reported, and Chartering Acts Passed by New York Assembly and Senate, 1830-1837

\begin{tabular}{|c|c|c|c|c|c|c|c|}
\hline & \multicolumn{3}{|l|}{ Assembly } & \multicolumn{2}{|c|}{ Senate } & \multicolumn{2}{|c|}{ House \& Senate } \\
\hline & Petitions & Bills & Bills & Petitions & Bills & Bills & Chartering \\
\hline & Received & Reported & Passed & Received & Reported & Passed & Acts \\
\hline 1830 & 23 & 22 & 12 & 37 & 34 & 13 & 9 \\
\hline 1831 & 54 & 36 & 26 & 27 & 26 & 20 & 9 \\
\hline 1832 & 91 & 49 & 19 & 23 & 19 & 16 & 7 \\
\hline 1833 & 83 & 38 & 22 & 39 & 26 & 12 & 8 \\
\hline 1834 & 92 & 31 & 21 & 33 & 24 & 13 & 8 \\
\hline 1835 & 20 & 4 & 2 & 1 & 1 & 1 & 0 \\
\hline 1836 & 118 & 54 & 32 & 36 & 28 & 19 & 12 \\
\hline 1837 & 54 & 2 & 0 & 3 & 0 & 0 & 0 \\
\hline Totals & 535 & 236 & 134 & 199 & 158 & 94 & 53 \\
\hline
\end{tabular}

Sources: Albany Evening Journal, various issues, 1830 - 1837. 
Table 3

Per Capita Bank Capital by New York State Senate District

\begin{tabular}{|c|c|c|c|c|}
\hline Senate & \multicolumn{4}{|c|}{ Per capita Bank Capital } \\
\hline District & 1830 & 1837 & 1850 & 1857 \\
\hline I & $\$ 51.18$ & $\$ 56.17$ & $\$ 36.56$ & $\$ 65.38$ \\
\hline II & 1.77 & 7.44 & 9.22 & 12.07 \\
\hline III & 11.67 & 19.04 & 16.50 & 33.02 \\
\hline IV & 0.45 & 3.43 & 4.91 & 10.94 \\
\hline V & 2.45 & 8.56 & 11.13 & 16.14 \\
\hline VI & 1.49 & 5.64 & 5.43 & 10.50 \\
\hline VII & 5.66 & 9.37 & 8.75 & 12.41 \\
\hline VIII & 1.25 & 6.64 & 9.04 & 14.44 \\
\hline Gini Index & 0.69 & 0.48 & 0.35 & 0.36 \\
\hline $\begin{array}{l}\text { Counties with } \\
\text { no banks }\end{array}$ & $66.1 \%$ & $26.8 \%$ & $15.5 \%$ & $5.2 \%$ \\
\hline
\end{tabular}

Notes: District I includes New York City and Long Island; District II, the counties just north of New York City; District III, the counties surrounding Albany; District IV, the Adirondacks; District V, the Syracuse, Oswego, Watertown areas; District VI, the Southern Tier, around Binghampton; District VII, the Finger Lakes region; and, District VIII, the western counties from Rochester to Buffalo and south to the Pennsylvania border.

Sources: U.S. State Department, Fifth Census (1830); U.S. State Department, Sixth Census (1840); U.S. Census Office, Seventh Census (1850); U.S. Census Office, Eighth Census (1860); New York State Assembly Document No. 59 (1831); New York State Assembly Document No. 71 (1838); Daily Albany Argus (25 November 1850); New York State Assembly Document No. 4 (1858). 